\title{
Obituary
}

\section{Professor F. V. Hunt}

A LEADING world authority on acoustical engineering, Professor F. V. Hunt died suddenly on April 20, 1972, during the Spring Meeting of the American Acoustical Society at Buffalo. He had been ill intermittently for the past six years but he still retained his effervescent spirit and even on the night of his death had participated fully in some lively discussions.

Born in Barnesville, Ohio, in 1905, Ted Hunt entered Ohio University in 1921 at the age of 16 and, following graduation in the summer of 1925 , he started his lifelong interest in automobile touring by selling his silver flute to purchase a Ford car. These yearly travels were depicted in a fascinating manner on greeting cards to his many friends at Christmas. Just prior to his PhD award at Harvard in 1934, for a thesis on frequency modulated signals in reverberation measurements, he married Katherine Buckingham whose father was a Bureau of Standards physicist and was the originator of the $\pi$-theorem of dimensional analysis. By 1941 Hunt had become Associate Professor of Physics and Communication Engineering at Harvard Underwater Sound Laboratory (HUSL) and in 1942 he became director of the laboratory. The laboratory's objectives were to improve existing equipment and to design new equipment for submarine detection and localization. At the peak of activity in 1944 the laboratory staff reached a total of 450 .

The most important products of HUSL were the scanning sonar and the acoustic torpedo, the latter device being probably the first guided missile, and remarkably it was designed and in operation within eighteen months. An interesting by-product was the acoustic "beeper" which could be attached to a torpedo during proof testing and helped locate torpedoes which had become wayward in action.

In 1946 he became the Gordon McKay Professor of Applied Physics, and he also held the Rumford chair in the department of physics from 1953.

Hunt was dedicated to his field of study and for over thirty years did not miss a single meeting of the American Acoustical Society. He was the recipient of many honours and from his country he received the Presidential Medal of Merit and the Navy Distinguished Public Service Medal, from the American Acoustical Society the Pioneers of Underwater Acoustics Medal and the Society Gold Medal (he was President of the AAS in 1951), and from the Audio Engineering Society the Potts Memorial Award. His greatest satisfaction, however, stemmed from the great affection in which he was held by bis many graduate students, who are living evidence of the high academic standard of their training.

After his retirement two years ago Hunt continued work as a research associate at the Marine Physical Laboratory of the Scripps Institution of Oceanology. $\mathrm{He}$ will be greatly missed by his family and his friends.

\section{Announcements}

\section{University News}

Professor Clement Camford has been appointed a Pro-Vice-Chancellor at the University of Liverpool.

\section{International Meetings}

September 3-9, IXth International Congress of Nutrition, Mexico City (IX Congreso Internacional de Nutrición, PO Box 22-112, México, D.F. México).

September 4-15, Science and Technology of Electronic Materials, Lake Como (Professor U. Colombo, Director, Strategic Planning, Montecatini Edison S.p.A., Largo Donegani, 2, 20121 Milan).

September 5-7, International Symposium of the Occupational Safety and Health of Young Workers, Belgrade (Occupational Safety and Health Branch, International Labour Office, 1211 Geneva 22).

September 5-7, Recent Mathematical Developments in Control, Bath (Secretary, Institute of Mathematics and Its Applications, Maitland House, Warrior Square, Southend-on-Sea, Essex SS1 2JY).
September 5-8, Plant Cell Protoplasts and their Molecular Biological Implications, Tubingen (Professor Georg Melchers, D 74 Tubingen, Corrensstr. 41, MaxPlanck-Institut für Biologie).

September 10-23, Summer School in Theoretical Chemistry, Oxford (Professor C. A. Coulson, Mathematical Institute, 24-29 St Giles, Oxford OX1 3LB).

September 12-15, VIIIth International Federation of Societies of Cosmetic Chemists, Congress, Hamburg (Dr Herbert P. Fiedler, D-62 Wiesbaden, Lanzstrasse 4, Germany).

September 13-15, VIIth International Symposium on Chromatography and Electrophoresis, Brussels (Secretariat of the Belgian Society of Pharmaceutical Sciences, 11 rue Archimède, 1040 Brussels).

September 15-17, Social Responsibility and Education in Physics, Leeds (Meetings Officer, Institute of Physics, 47 Belgrave Square, London, SW1X 8QX).

September 20-21, Offshore Engineering, Edinburgh (Arthur C. Gardiner, Director of Unilink, Heriot-Watt University, 79 Grassmarket, Edinburgh EH1 2HJ).

September 20-27, Workshop on Electromagnetic Induction, Edinburgh (Dr B. A. Hobbs, Department of Geophysics, University of Edinburgh, 6 South Oswald Road, Edinburgh EH9 2HX).
September 25-26, Electro-Optic Systems in Flow Measurement, Southampton (Clive Greated, University of Southampton, Department of Mathematics, Southampton $\mathrm{SO} 95 \mathrm{NH}$ ).

September 25-27, Groundwater Pollution, Reading (Water Research Association, Medmenham, Marlow, Buckinghamshire SL7 2HD).

September 29, Amino-sugar Synthesis and Reactions, London (Dr N. R. Williams, Chemistry Department, Birkbeck College, Malet Street, London WC1E 7HX).

\section{Reports and Publications}

not included in the Monthly Books Supplement

\section{Great Britain and Ireland}

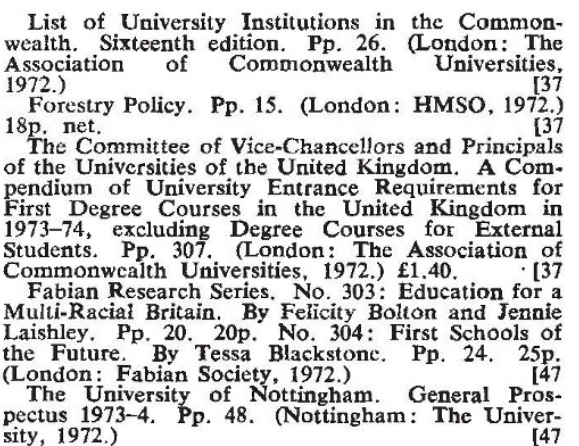

wealth. Sixteenth edition. of Commonwealth Universities

$18 \mathrm{p} . \mathrm{n}$ of the Universities of the United Kingdom. A Com pendium of University Entrance Requirements for First Degree Courses in the United Kingdom in 1973-74, excluding Degree Courses for Externa Students. Pp. 307. (London: The Association of Fabian Research Series, No 303. Education for Multi-Racial Britain. By Felicity Bolton and Jennie the Future. By Tessa Blackstone. Pp. 24. 25p (London: Fabian Society, 1972.) [4] pectus 1973-4. Pp. 48. (Nottingham: The Univer- 